The content of vitamins and microelements in vegetable pozders, flour of legumes and in bread made with their use was investigated. The degree of staling of gluten-free bread was determined and, on the basis of the obtained regularities, the timing of the sale of special bread was scientifically substantiated and experimentally confirmed. The relevance of the studies carried out is due to the shortage of special dietary consumption products, the under-filling of the market for which is about $23 \%$ of the total production. As a result of the study, it was found that the composition of the powder from carrots of the Daucus carota variety and the powder from the beets of the Beta vulgaris $L$. variety contained vitamins: $A, E, C, B_{1}, B_{5}, B_{6}, B_{9}, B_{12}, K, P P$ and trace elements: $\mathrm{Ca}, \mathrm{Mg}, \mathrm{Fe}, \mathrm{Cu}, \mathrm{I}, \mathrm{Se}$, $Z n$. Vitamins $A, E, C, B_{6}, B_{9}, B_{12}$ and microelements: $\mathrm{Mg}, \mathrm{Fe}, \mathrm{Cu}, \mathrm{I}, \mathrm{Se}, \mathrm{Zn}$ are found in soy and chickpea flour. The degree of nutrient retention after the manufacture of specialized bread and after 72 hours of storage has been determined. Losses occur in the content of vitamins $A, E, C$ and trace elements $\mathrm{Fe}, \mathrm{Cu}$. After 72 hours of storage, the developed types of bread, provided that $100 \mathrm{~g}$ per day are consumed, cover $50 \%$ of the daily requirement for fortified vitamins and microelements. It has been established that the terms of sale of the "Protein" bread are 48 hours. The sales terms of "Carrot" and "Beet" bread are 72 hours, the decrease in the degree of staling of the bread is due to the use of vegetable powders (carriers of pectin), which is confirmed by an increase in the hydrophilic properties of the crumb of bread. The established patterns are important for scientists that they are working on the creation of gluten-free bread for dietary nutrition with improved quality indicators during storage, which is one of the priority and urgent tasks of the food industry

Keywords: bean flour, vegetable powders, special dietary bread, vitamins, microelements

Received date 05.09.2020

Accepted date 26.10.2020

Published date 30.10.2020
UDC 664.66: 546.15

DOI: $10.15587 / 1729-4061.2020 .215019$

\section{INVESTIGATION OF CHANGE OF QUALITY INDICATORS OF GLUTEN- FREE BREAD DURING STORAGE}

\author{
Y. Biletska \\ $\mathrm{PhD}^{*}$ \\ E-mail: ya.belecka@karazin.ua \\ G. D j u k a r e va \\ $\mathrm{PhD}$, Associate Professor** \\ E-mail: d.galina@gmail.com \\ A. Nek os \\ Doctor of Geographical Sciences, Professor \\ Department of Ecological Safety and Environmental Education \\ Karazin Institute of Environmental Sciences \\ V. N. Karazin Kharkiv National University \\ Svobody sq., 4, Kharkiv, Ukraine, 61022 \\ E-mail: a.nekos999@gmail.com \\ A. Husliev \\ $\mathrm{PhD*}$ \\ E-mail: gusilev@karazin.ua \\ A. Krivtsova \\ $\mathrm{PhD*}$ \\ E-mail: anna.perepelytsia@karazin.ua \\ Svobody sq., 4, Kharkiv, Ukraine, 61022 \\ M. B a kirov \\ $\mathrm{PhD}$ \\ Department of Hotel and Restaurant Business and Merchandise \\ University of Customs and Finance \\ Volodymyra Vernadskoho str., 2/4, Dnipro, Ukraine, 49000 \\ E-mail: bakirov_mp@ukr.net \\ V. Polupan \\ $\mathrm{PhD}$ ** \\ E-mail: valvad@gmail.com \\ V. On y s h chenko \\ $\mathrm{PhD}$, Associate Professor** \\ E-mail: onam70@gmail.com \\ E. Sokolova \\ $\mathrm{PhD}$ \\ Department of Commodity Science, Trade and \\ Quality Management of Goods*** \\ E-mail: evgeniya-sokolova@ukr.net \\ *Department of International E-commerce and Hotel\&Restaurant Business \\ V. N. Karazin Kharkiv National University \\ Svobody sq., 4, Kharkiv, Ukraine, 61022 \\ **Department of Merchandising in Customs Affairs*** \\ ***Kharkiv State University of Food Technology and Trade \\ Klochkivska str., 333, Kharkiv, Ukraine, 61051
}

\section{Introduction}

Bread is the most readily available mass consumption product. The creation of special dietary food products with
Copyright (C) 2020, Y. Biletska, G. Djukareva, A. Nekos, A. Husliev, A. Krivtsova,

M. Bakirov, V. Polupan, V. Onyshchenko, E. Sokolova

This is an open access article under the CC BY license (http://creativecommons.org/licenses/by/4.0) 
A new technology is proposed [3] for the use of chickpea paste to improve the texture of gluten-free bread. It has been shown to be a promising substitute for hydrocolloids such as xanthan gum. It has been found that chickpea paste exhibits water- and oil-binding and emulsifying properties that can improve the texture of gluten-free bread and extend its shelf life by 12 hours. A new technological method is [5] the use of artichoke fiber in baked goods for special purposes. It has been found that the addition of artichoke fiber in the amount of $10 \%$ to the flour mass increases the specific volume of bread by $4.2 \%$ and by 16 hours of sale.

Technological methods proposed above are not carriers of vitamins and microelements, the deficiency of which is observed in $70 \%$ of the population requiring special nutrition. It is necessary to develop gluten-free products with high organoleptic characteristics, improved nutritional value and long shelf life [6]. In the production of gluten-free bread, there is a complete extraction of gluten, which plays an important role in the formation of organoleptic characteristics and the shelf life of bread. Therefore, it is relevant and necessary to use food ingredients that have the ability to positively influence these indicators.

The technology of legume flour enriched with iodine and selenium has been developed [7,8]. To expand the range, improve the organoleptic characteristics of bread, the use of carrot and beet powder is justified [7], but the content of vitamins and microelements in the used food ingredients (bean flour and vegetable powders) has not been studied. The content of vitamins and microelements in bread during storage has not been determined, but the degree of staling of the developed gluten-free bread has not been investigated.

Relevant for the present is the conduct of this complex of studies, since there is not enough data on solving the above issues, it is necessary to deepen and expand research in this direction.

\section{Literature review and problem statement}

Improving the quality, nutritional value, extending the shelf life, expanding the range of special breads contributes to the implementation of the modern concept of healthy nutrition [9].

Scientific work [10] proves that bread made on the basis of gluten-free flour has a shorter implementation time than bread made on wheat flour. Staling of special bread is observed 48 hours after production. The developers believe that the stale process of gluten-free bread is the result of drying out. In order to extend the period for the sale of special bread in the works [11,12] proposed the use of functional ingredients obtained from industrial by-products. Their disadvantage is that they only affect the extension of the sale period of bread, without increasing its biological value.

There is a method [13] for making bread with increased nutritional and biological value, according to which isolates of vegetable proteins of peas and soybeans are used, together with corn flour. This method is proposed for persons with overweight and gluten intolerance. Bread according to the developed technology has a high protein content and a low fat content, but is not a carrier of vitamins and microelements.
The known method [14] making a special bread using rice, corn, buckwheat flour together with dry vegetable powders. The content of vegetable powders provides finished products with vitamins A, B, E. Bread according to the developed technology contributes to a significant reduction in sugar content, the intake of vitamins and the absence of gluten. The disadvantage of this method of bread production is the lack of trace elements in its composition.

In [4], the influence of the use of microalgae Isochrysis galbana, Tetraselmis suecica, Scenedesmus almeriensis and Nannochloropsis gaditana on the physicochemical and textural properties of gluten-free bread was studied. It has been found that their use has a positive effect on the hardness, chewing and elasticity of specialized bread during its sale. A hypothesis has been put forward about the enrichment with microelements, which are carried by microalgae. The disadvantage of this research is only a theoretical substantiation of the content of trace elements, without experimental confirmation. The reason for this may be difficulties associated with the complexity of conducting research to determine the content of trace elements.

To solve this scientific problem, scientists have proposed the use of the method of stripping voltammetry [15], when determining the content of trace elements in special bread containing brown seaweed. The developed types of bread [16], with the content of brown seaweed, which are carriers of trace elements and vitamins, have "non-classical" organoleptic characteristics - green inclusions and algae aftertaste. It is known [17] that the consumer is "distrustful" of unusual organoleptic characteristics, Also, the developers describe the loss of microelements up to $80 \%$ when baking bread. The content of microelements during storage of bread has not been studied at all. Bread can't be classified as a special product, which, according to the principle of nutritional science, should provide $20-50 \%$ of the daily requirement for fortified nutrients.

All of the above technological approaches used by the inventors to develop special bread have disadvantages. Among them: deterioration of organoleptic characteristics, significant losses of trace elements during baking, an increase in only the period of consumption without increasing the biological and nutritional value. There is a lack of scientific papers on the determination of the content of trace elements and vitamins in special bread. The reason for this may be difficulties associated with the complexity of their definition. Vitamins and trace elements are quite unstable compounds capable of oxidation, transformation, evaporation.

In [18], it is found that changes in gluten-free bread during storage are associated not only with drying, but also with a change in the state of the molecules of the bread components. For a comprehensive study of the essence of the staling process, it is advisable to use a differential organoleptic assessment of the degree of freshness (staling) of bread. Studying the change in porosity, moisture, fragility, crumb swelling, let's calculate a complex organoleptic indicator. Let's consider it promising to pay attention to the study of the laws that influence these processes. Carrying out this complex of research is necessary, since deepening and expanding research in this direction will allow improving the recipe for special bread, the market gap for which is about $15 \%$ of the total production of bakery products. 


\section{The aim and objectives of research}

The aim of research is to determine the effect of vegetable powders and legume flour on changes in the quality indicators of gluten-free bread during storage.

This will provide an opportunity to obtain a number of regularities that will form the basis for improving the recipe for gluten-free bread, which will predictably be enriched in nutrients and with an extended shelf life.

To achieve the aim, the following objectives are set:

- to investigate the content of vitamins and microelements in the used food ingredients - vegetable powders and bean flour;

- to determine the content of vitamins and microelements in bread during storage;

- to investigate the degree of staling of gluten-free bread.

\section{Materials and methods of research study of quality} indicators of gluten-free bread during storage

4. 1. Characteristics of food ingredients and research methods of the content of vitamins and microelements

Daucus carota carrot vegetable powder and Beta vulgaris $L$ beet powder. Powders are made in accordance with TU U 15.3-23913766:002:2005 "Finely dispersed vegetable and fruit-berry powders". Early maturing varieties of soybeans and chickpeas "Almaz" and "Krasnokutskyi 195" (respectively). Legume flour is made in accordance with TU U 10.6-02071205-001:2019 "food soy flour enriched with iodine" and TU U 10.6-02071205-002:2019 "Food chickpea flour enriched with selenium". Used raw materials grown on the grounds of the collection nursery "Agrotek" (Kiev, Ukraine.), Harvest 2018.

Determination of vitamins was carried out by the method of high performance liquid chromatography using a chromatograph "Liumakhrom" (Russia, St. Petersburg) and detectors: spectrophotometric -3220 ; fluorometric -2410 . Determination of vitamin A content was carried out by the amount of carotenoid pigments.

The content of the mass fraction of trace elements was determined by the "stripping - voltammetry" method using a voltammetric analyzer "AVA" (St. Petersburg, Russia), which is equipped with indicator electrodes for determining the mass fraction of various trace elements.

\section{2. Characteristics of bread samples and research} methods of vitamins and microelements during storage

The production of prototypes of bread provides for the preparation of dough without gluten-free raw materials containing soybean meal enriched with iodine, chickpea meal enriched with selenium in a ratio of 1: 1 and vegetable powders. Bread recipes "Protein", "Carrot," Beetroot "are shown in Tables 1-3. A well-known bread recipe was taken as control [19], which is used in the bakery industry for consumption by people with celiac disease and diabetes. The recipe provides for the use of buckwheat flour, yeast, sugar - stevia, sunflower oil, salt and to improve the structure-forming properties of gluten-free bread xanthan gum, Table 4.

Determination of vitamins was performed by high performance liquid chromatography. The content of the mass fraction of microelements was determined by the method of "stripping - voltammetry".
Table 1

Recipe ingredients for "Protein" bread, g/kg

\begin{tabular}{|c|c|}
\hline Buckwheat flour & 880 \\
\hline Chickpea flour & 48 \\
\hline Soy flour & 48 \\
\hline Yeast & 5 \\
\hline Table salt & 4 \\
\hline Sugar - stevia & 5 \\
\hline Sunflower oil & 5 \\
\hline Xanthan gum & 5 \\
\hline Total & 1,000 \\
\hline
\end{tabular}

Table 2

Recipe ingredients for "Carrot" bread, g/kg

\begin{tabular}{|c|c|}
\hline Buckwheat flour & 755 \\
\hline Chickpea flour & 48 \\
\hline Soy flour & 48 \\
\hline Potato starch & 25 \\
\hline Carrot powder & 100 \\
\hline Yeast & 5 \\
\hline Table salt & 4 \\
\hline Sugar - stevia & 5 \\
\hline Sunflower oil & 5 \\
\hline Xanthan gum & 5 \\
\hline Total & 1,000 \\
\hline
\end{tabular}

Table 3

Recipe ingredients for "Beetroot" bread, g/kg

\begin{tabular}{|c|c|}
\hline Buckwheat flour & 755 \\
\hline Chickpea flour & 48 \\
\hline Soy flour & 48 \\
\hline Potato starch & 25 \\
\hline Beet powder & 100 \\
\hline Yeast & 5 \\
\hline Table salt & 4 \\
\hline Sugar - stevia & 5 \\
\hline Sunflower oil & 5 \\
\hline Xanthan gum & 5 \\
\hline Total & 1,000 \\
\hline
\end{tabular}

Table 4

Recipe ingredients of the control bread sample, $\mathrm{g} / \mathrm{kg}$

\begin{tabular}{|c|c|}
\hline Buckwheat flour & 976 \\
\hline Yeast & 5 \\
\hline Table salt & 4 \\
\hline Sugar - stevia & 5 \\
\hline Sunflower oil & 5 \\
\hline Xanthan gum & 5 \\
\hline Total & 1,000 \\
\hline
\end{tabular}

4.3. Methods of researching the staling degree of gluten-free bread

To study the essence of the staling process, a differentiated organoleptic assessment of the degree of freshness (staling) of bread was used, [20]. According to this assessment, let's use the change in indicators such as porosity, moisture, fragility, crumb swelling and a complex organoleptic indicator. Products were tested 4, 48 and 72 hours after manufacture. The prototypes of bread were 
stored unpacked at a temperature of $20 \pm 2{ }^{\circ} \mathrm{C}$ and an air humidity of $75 \pm 2 \%$.

Micrographs of the structure of the crumb of bread were studied on a trinocular fluorescent microscope "Microderm" (Moscow, Russia), at a magnification of $16 \times 100$ times.

\section{Research results of quality indicators of gluten-free bread during storage}

5. 1. Research of the content of vitamins and microelements in vegetable powders and bean flour

Table 5 shows the results of a study of the content of vitamins and microelements in vegetable powders and bean flour.

Note: \% of daily requirement for vitamins and minerals is calculated for women 25-45 years with average intensity of work.

As a research result, it is found that the composition of the powder from carrots of the Daucus carota variety and the powder from the beets of the Beta vulgaris $L$. variety contains vitamins: A, E, C, $\mathrm{B}_{1}, \mathrm{~B}_{5}, \mathrm{~B}_{6}, \mathrm{~B}_{9}, \mathrm{~B}_{12}, \mathrm{~K}, \mathrm{PP}$ and microelements: $\mathrm{Ca}, \mathrm{Mg}, \mathrm{Fe}, \mathrm{Cu}, \mathrm{I}, \mathrm{Se}, \mathrm{Zn}$. The content of vitamins $\mathrm{A}, \mathrm{E}, \mathrm{C}, \mathrm{B}_{1}, \mathrm{~B}_{5}, \mathrm{~B}_{6}, \mathrm{~B}_{9}, \mathrm{~K}, \mathrm{PP}$ in the Daucus carota carrot powder was $1.2 ; 0.40 ; 16.00 ; 0.60$; $1.30 ; 0.07 ; 0.05 ; 0.09 ; 6.00 \mathrm{mg}$ respectively. The content of trace elements $\mathrm{Ca}, \mathrm{Mg}, \mathrm{Fe}, \mathrm{Cu}, \mathrm{Se}, \mathrm{Zn}$ was $0.05 ; 13.5 ; 3.90 ; 0.035 ; 0.01 ; 1.3 \mathrm{mcg}$, respectively. The content of vitamins $\mathrm{C}, \mathrm{B}_{1}, \mathrm{~B}_{5}, \mathrm{~B}_{6}, \mathrm{~B}_{9}, \mathrm{~B}_{12}$ in the composition of the powder from beet varieties Beta vulgaris $L$. was $21.0 ; 0.50 ; 1.40 ; 0.09 ; 0.07 ; 0.01 \mathrm{mg}$, respectively. The content of trace elements: $\mathrm{Ca}, \mathrm{Mg}, \mathrm{Fe}, \mathrm{Cu}, \mathrm{I}, \mathrm{Zn}$ was $0.02 ; 12.5$ (mg) $1.6 ; 0.025 ; 0.01 ; 0.8$, $\mu$ g, respectively. The content of vitamins A, E, C, B 6 , B ${ }_{9}, \mathrm{~B}_{12}$ in soy flour was $0.2 ; 2.4 ; 19 ; 3.0 ; 0.4 ; 0.03 \mathrm{mg}$, respectively; and chickpea flour - 0.4; 3.8; sixteen; 0.35 ; 0.37; $0.028 \mathrm{mg}$, respectively. The content of trace elements $\mathrm{Mg}, \mathrm{Fe}, \mathrm{Cu}$, and, $\mathrm{Zn}$ in the composition of soy flour was $410 ; 10,0.1$; 50; 10 microgram, respectively. Content of trace elements $\mathrm{Mg}, \mathrm{Fe}, \mathrm{Cu}, \mathrm{Se}, \mathrm{Zn}$ in the composition of chickpea flour was $335 ; 8.0,0.05 ; 52 ; 11$ microgram, respectively.

Analyzing the results of the study, it can be argued that soy flour does not contain vitamins $B_{1}$ in its composition; $\mathrm{B}_{5}, \mathrm{~K}, \mathrm{PP}$ and trace element $\mathrm{Ca}$ and $\mathrm{Se}$. The obtained data on the content of vitamins and microelements in chickpea flour differ from soybean only in the content of Se, which is present in the developed product due to its accumulation during soaking. Beet powder of Beta vulgaris $L$. variety does not contain the microelement Se and vitamins A, E, K, PP. Daucus carota carrot powder contains deficient vitamins $\mathrm{K}$ and $\mathrm{PP}$, but there is also no Se content.

The absence of vitamins $B_{1}$ and $B_{5}$ in the flour can affect the degree of assimilation of $\mathrm{B}$ vitamins. It is known [21] that they enhance the assimilation of each other; however, a high content of vitamin E (2.4 and 3.8 at a daily rate of $2 \mathrm{mg}$ ) will correct the predicted consequences due to increased assimilation of B vitamins. This synergism of substances is described and experimentally confirmed in [22].

The content of vitamins and microelements in the composition of vegetable powders and bean flour

\begin{tabular}{c|c|c|c|c|c|}
\multirow{2}{*}{ Indicator } & \multirow{2}{*}{$\begin{array}{c}\text { Daily } \\
\text { require- } \\
\text { ment }\end{array}$} & \multicolumn{7}{|c|}{ Powder } & \multicolumn{2}{c|}{ Flour } \\
\cline { 3 - 6 } & \multicolumn{6}{|c|}{ Vitamins, mg } \\
\hline $\mathrm{A}$ & 0.80 & $1.20 \pm 0.02$ & - & $0.2 \pm 0.02$ & $0.4 \pm 0.02$ \\
\hline $\mathrm{E}$ & 2.00 & $0.40 \pm 0.002$ & - & $2.4 \pm 0.02$ & $3.8 \pm 0.02$ \\
$\mathrm{C}$ & 55.00 & $16.00 \pm 0.2$ & $21.0 \pm 0.2$ & $19 \pm 0.2$ & $16 \pm 0.2$ \\
\hline $\mathrm{B}_{1}$ & 1.30 & $0.60 \pm 0.02$ & $0.50 \pm 0.02$ & - & - \\
\hline $\mathrm{B}_{5}$ & 5.50 & $1.30 \pm 0.02$ & $1.40 \pm 0.02$ & - & - \\
\hline $\mathrm{B}_{6}$ & 0.20 & $0.07 \pm 0.002$ & $0.09 \pm 0.002$ & $3.0 \pm 0.002$ & $0.35 \pm 0.002$ \\
\hline $\mathrm{B}_{9}$ & 0.20 & $0.05 \pm 0.0002$ & $0.07 \pm 0.0002$ & $0.4 \pm 0.0002$ & $0.37 \pm 0.0002$ \\
\hline $\mathrm{B}_{12}$ & 0.03 & - & $0.01 \pm 0.002$ & $0.03 \pm 0.002$ & $0.028 \pm 0.002$ \\
\hline $\mathrm{K}$ & 0.12 & $0.09 \pm 0.002$ & - & - & - \\
\hline $\mathrm{PP}$ & 20.00 & $6.00 \pm 0.2$ & - & - & - \\
\hline \multicolumn{7}{|c|}{ Microelements, microgram } \\
\hline $\mathrm{Ca}$ & 2.00 & $0.05 \pm 0.002$ & $0.02 \pm 0.002$ & - & - \\
\hline $\mathrm{Mg}$ & 350.00 & $13.50 \pm 0.2$ & $12.5 \pm 0.2$ & $410.0 \pm 0.2$ & $335 \pm 0.2$ \\
\hline $\mathrm{Fe}$ & 10.00 & $3.90 \pm 0.2$ & $1.60 \pm 0.2$ & $10.0 \pm 0.2$ & $8.0 \pm 0.2$ \\
\hline $\mathrm{Cu}$ & 0.10 & $0.035 \pm 0.0002$ & $0.025 \pm 0.0002$ & $0.1 \pm 0.0002$ & $0.05 \pm 0.0002$ \\
\hline $\mathrm{I}$ & 0.15 & - & $0.01 \pm 0.2$ & $50 \pm 0.2$ & - \\
\hline $\mathrm{Se}$ & 0.07 & $0.01 \pm 0.002$ & - & - & $52 \pm 0.02$ \\
\hline $\mathrm{Zn}$ & 10.00 & $1.3 \pm 0.02$ & $0.8 \pm 0.02$ & $10.0 \pm 0.2$ & $11 \pm 0.2$ \\
\hline
\end{tabular}

\section{2. Determination of the content of vitamins and} microelements in bread during storage

The results of the content of vitamins and trace elements in bread for special dietary consumption during storage are shown in Table 6.

Table 6

Content of vitamins and microelements in gluten-free bread during storage

\begin{tabular}{|c|c|c|c|c|c|c|}
\hline \multirow{2}{*}{$\begin{array}{l}\text { Indi- } \\
\text { cator }\end{array}$} & \multicolumn{2}{|c|}{ «Protein» } & \multicolumn{2}{|c|}{ «Carrot» } & \multicolumn{2}{|c|}{ «Beetroot» } \\
\hline & $6 \mathrm{~h}$ & $72 \mathrm{~h}$ & $6 \mathrm{~h}$ & $72 \mathrm{~h}$ & $6 \mathrm{~h}$ & $72 \mathrm{~h}$ \\
\hline \multicolumn{7}{|c|}{ Vitamins, mg } \\
\hline A & $0.3 \pm 0.02$ & $0.2 \pm 0.02$ & $6.5 \pm 0.02$ & $5.2 \pm 0.02$ & $0.3 \pm 0.02$ & $0.2 \pm 0.02$ \\
\hline $\mathrm{E}$ & $2.9 \pm 0.02$ & $2.2 \pm 0.02$ & $3.5 \pm 0.02$ & $3.0 \pm 0.02$ & $3.1 \pm 0.02$ & $2.9 \pm 0.02$ \\
\hline $\mathrm{C}$ & $15 \pm 0.2$ & $5 \pm 0.2$ & $33.5 \pm 0.02$ & $13.5 \pm 0.02$ & $35.0 \pm 0.02$ & $12.0 \pm 0.02$ \\
\hline $\mathrm{B}_{1}$ & - & - & $0.60 \pm 0.02$ & $0.60 \pm 0.02$ & $0.5 \pm 0.02$ & $0.5 \pm 0.02$ \\
\hline $\mathrm{B}_{5}$ & - & - & $1.30 \pm 0.02$ & $1.30 \pm 0.02$ & $1.4 \pm 0.02$ & $1.4 \pm 0.02$ \\
\hline $\mathrm{B}_{6}$ & $3.2 \pm 0.02$ & $3.2 \pm 0.02$ & $1.74 \pm 0.02$ & $1.74 \pm 0.02$ & $1.74 \pm 0.02$ & $1.74 \pm 0.02$ \\
\hline $\mathrm{B}_{9}$ & $1.8 \pm 0.02$ & $1.8 \pm 0.02$ & $0.43 \pm 0.02$ & $0.43 \pm 0.02$ & $1.74 \pm 0.02$ & $1.74 \pm 0.02$ \\
\hline $\mathrm{B}_{12}$ & 0.027 & 0.027 & 0.029 & 0.029 & 0.039 & 0.039 \\
\hline $\mathrm{K}$ & - & - & $0.09 \pm 0.002$ & $0.09 \pm 0.002$ & - & - \\
\hline $\mathrm{PP}$ & - & - & $6.00 \pm 0.2$ & $6.00 \pm 0.2$ & - & - \\
\hline \multicolumn{7}{|c|}{ Vitamins, microgram (Mg) } \\
\hline $\mathrm{Ca}$ & - & - & $0,05 \pm 0,2$ & $0,05 \pm 0,2$ & $0,02 \pm 0,02$ & $0,02 \pm 0,02$ \\
\hline $\mathrm{Mg}$ & $365 \pm 0.2$ & \begin{tabular}{|l|}
$365 \pm 0.02$ \\
\end{tabular} & $386 \pm 0.2$ & $386 \pm 0.2$ & $377 \pm 0.02$ & $377 \pm 0.02$ \\
\hline $\mathrm{Fe}$ & $9.0 \pm 0.02$ & $8.0 \pm 0.02$ & $12.9 \pm 0.2$ & $10.9 \pm 0.2$ & $10.6 \pm 0.02$ & $9.4 \pm 0.02$ \\
\hline $\mathrm{Cu}$ & 0.075 & 0.063 & 0.11 & 0.10 & 0.1 & 0.08 \\
\hline $\mathrm{I}$ & $25.0 \pm 0.02$ & $25.0 \pm 0.02$ & $25.0 \pm 0.2$ & $25.0 \pm 0.2$ & $25 \pm 0.02$ & $25 \pm 0.02$ \\
\hline $\mathrm{Se}$ & $26.0 \pm 0.02$ & $26.0 \pm 0.02$ & $26.0 \pm 0.2$ & $26.0 \pm 0.2$ & $26 \pm 0.02$ & $26 \pm 0.02$ \\
\hline $\mathrm{Zn}$ & $10.5 \pm 0.02$ & $10.0 \pm 0.02$ & $12.3 \pm 0.2$ & $12.3 \pm 0.2$ & $11.3 \pm 0.02$ & $11.3 \pm 0.02$ \\
\hline
\end{tabular}


The content of vitamins and microelements in bread was determined during 72 hours of storage. It was found that the losses occur in the content of vitamins $\mathrm{A}, \mathrm{E}, \mathrm{C}$ and trace elements $\mathrm{Fe}, \mathrm{Cu}$. The content of vitamins A, E, C decreases by $0.1 ; 0.7$; $10.0 \mathrm{mg}$ in "Protein" bread, 1.3; 0.5; $20.0 \mathrm{mg}$ - in carrot bread, 0.1; 0.2; $23 \mathrm{mg}$ - in Beetroot bread. The content of $\mathrm{Fe}, \mathrm{Cu}$ after 72 hours of storage decreases by $0.1 ; 0.012 \mathrm{mg}$ in "Protein" bread, by 2.0; $0.01 \mathrm{mg}$ - in "Carrot" bread, by 1.2; $0.02 \mathrm{mg}-$ in "Beetroot" bread. 72 hours after production, types of bread were developed, for consumption of $100 \mathrm{~g}$ per day, covers $50 \%$ of the daily requirement for fortified vitamins and minerals.

\section{3. Research on the degree of staling of gluten-free bread}

Table 7 presents the results of a study of the staling degree of gluten-free bread.

It was experimentally established that the change in organoleptic parameters in gluten-free bread during storage was reflected in such indicators as porosity and fragility. In all test samples, crumb fragility was observed during storage. In the control sample and in the sample of "Protein" bread 72 hours after baking, the complex organoleptic assessment of staling was 3.5 and 3.9 points (respectively). The porosity of the "Protein" bread decreases from 64.4 to 61.1 and $58.4 \%$, from 4:00 after production and 48 and 72 hours of storage. In terms of porosity, the samples of "Carrot" and "Beetroot" breads have better characteristics in comparison with the control and "Protein" bread \%. Porosity decreases from 69.7 to 67.9 and 65.7 in the "Carrot" bread sample and by 66.3 to 65.4 and 63.8 in the "Beetroot" bread sample (from 4.48 for 72 hours of storage, respectively).

It has been established that the use of vegetable powders in gluten-free bread has a positive effect during storage.

To substantiate this experimental result of a study to study the microstructure of the crumb of bread using flour and vegetable powders, the results of the study are presented in Fig. 1.

Research on the staling degree of gluten-free bread

\begin{tabular}{|c|c|c|c|c|c|}
\hline Sample & $\begin{array}{c}\text { Porosi- } \\
\text { ty, } \%\end{array}$ & $\begin{array}{c}\text { Crumb } \\
\text { moisture, \% }\end{array}$ & $\begin{array}{c}\text { Crum- } \\
\text { bling, \% }\end{array}$ & $\begin{array}{c}\text { Crumb swell- } \\
\text { ing, ml per 1 g } \\
\text { of dry matter }\end{array}$ & $\begin{array}{c}\text { Organoleptic } \\
\text { assessment, } \\
\text { staling, points } \\
\text { (max5) }\end{array}$ \\
\hline \multicolumn{5}{|c|}{$4 \mathrm{~h}$} \\
\hline Control & $66.0 \pm 0.2$ & $46.3 \pm 0.2$ & $5.6 \pm 0.2$ & $6.7 \pm 0.2$ & 5.0 \\
\hline Protein & $64.4 \pm 0.2$ & $47.0 \pm 0.2$ & $5.0 \pm 0.2$ & $6.9 \pm 0.2$ & 5.0 \\
\hline Carrot & $69.7 \pm 0.2$ & $45.9 \pm 0.2$ & $4.6 \pm 0.2$ & $7.5 \pm 0.2$ & 5.0 \\
\hline Beetroot & $66.3 \pm 0.2$ & $45.3 \pm 0.2$ & $4.9 \pm 0.2$ & $7.3 \pm 0.2$ & 5.0 \\
\hline \multicolumn{5}{|c|}{$48 \mathrm{~h}$} \\
\hline Control & $58.8 \pm 0.2$ & $43.4 \pm 0.2$ & $11.9 \pm 0.2$ & $4.9 \pm 0.2$ & 4.1 \\
\hline Protein & $61.1 \pm 0.2$ & $45.7 \pm 0.2$ & $11.4 \pm 0.2$ & $4.3 \pm 0.2$ & 4.5 \\
\hline Carrot & $67.7 \pm 0.2$ & $44.5 \pm 0.2$ & $9.2 \pm 0.2$ & $5.8 \pm 0.2$ & 4.9 \\
\hline Beetroot & $65.4 \pm 0.2$ & $44.2 \pm 0.2$ & $9.4 \pm 0.2$ & $5.4 \pm 0.2$ & 4.7 \\
\hline \multicolumn{5}{|l|}{$72 \mathrm{~h}$} \\
\hline Control & $55.4 \pm 0.2$ & $42.8 \pm 0.2$ & $17.4 \pm 0.2$ & $3.2 \pm 0.2$ & 3.5 \\
\hline Protein & $58.4 \pm 0.2$ & $44.6 \pm 0.2$ & $17.0 \pm 0.2$ & $3.1 \pm 0.2$ & 3.9 \\
\hline Carrot & $65.7 \pm 0.2$ & $44.3 \pm 0.2$ & $13.4 \pm 0.2$ & $6.8 \pm 0.2$ & 4.5 \\
\hline Beetroot & $63.8 \pm 0.2$ & $44.0 \pm 0.2$ & $13.5 \pm 0.2$ & $6.0 \pm 0.2$ & 4.3 \\
\hline
\end{tabular}

6. Discussion of the research results of determining the content of vitamins and

Table 7 microelements in bread for special dietary consumption

The content of vitamins and microelements in the used food ingredients - vegetable powders and bean flour was determined, Table 5. The results obtained are explained by the destruction of nutrients under the influence of high temperature, light, air oxygen, moisture and other factors that arose during the technological process and storage of bread. Vitamins are easily oxidized and destroyed when exposed to high temperatures. The temperature in the middle of the bread during baking is $180-200{ }^{\circ} \mathrm{C}$, which can explain the significant loss of the studied vitamins. The loss of trace elements can be explained by the isomerization process. Let's assume that it is the aforementioned biochemical process that influenced the losses of $\mathrm{Fe}, \mathrm{Cu}$; a similar experimental result was obtained in [23]. The content of $\mathrm{Ca}, \mathrm{Mg}$, I, Se, Zn within 72 hours 
after production covers $\leq 50 \%$ of the daily requirement when using $100 \mathrm{~g}$ of specialized bread per day. It is especially important to obtain results on the content of I, Se in bread. The preservation of the aforementioned trace elements can be explained by an organic bond, which is thermally stable and does not lend itself to the isomerization process, due to the bond with the amino acid.

In comparison with the existing methods, with the consumption of $100 \mathrm{~g}$ per day of "Carrot" bread, the human body will receive $150 ; 20 ; 29 ; 46 ; 23.6 ; 35 ; 25 ; 75 ; 30 \%$ of the daily requirement for vitamins $\mathrm{A}, \mathrm{E}, \mathrm{C}, \mathrm{B}_{1}, \mathrm{~B}_{5}, \mathrm{~B}_{6}, \mathrm{~B}_{9}$, $\mathrm{K}, \mathrm{PP}$, respectively. And also $2.5 ; 3.9 ; 39 ; 35 ; 14.2 ; 13 \%$ in trace elements $\mathrm{Ca}, \mathrm{Mg}, \mathrm{Fe}, \mathrm{Cu}, \mathrm{Se}, \mathrm{Zn}$, respectively. With the consumption of $100 \mathrm{~g}$ per day of "Beetroot" bread, 38.1 will enter the human body; $38.4 ; 25.4 ; 45 ; 35 ; 33.3 \%$ vitamins $\mathrm{C}, \mathrm{B}_{1}, \mathrm{~B}_{5}, \mathrm{~B}_{6}, \mathrm{~B}_{9}, \mathrm{~K}, \mathrm{PP}$, respectively. And also 1; 3.57; 16; $25 ; 6.6 ; 6.4 \%$ in trace elements $\mathrm{Ca}, \mathrm{Mg}, \mathrm{Fe}, \mathrm{Cu}$, and, $\mathrm{Zn}$, respectively.

According to the recipes of the "Protein", "Carrot", "Beetroot" bread, it is advisable to use $100 \mathrm{~g} / \mathrm{kg}$ of legume flour in a ratio of $1: 1$. When eating $100 \mathrm{~g}$ of bread with a content of $100 \mathrm{~g} / \mathrm{kg}$ of legume flour, more than $50 \%$ of the daily requirements for the above studied vitamins and minerals. In accordance with the principles of nutritional science developed types of bread are classified as special [8]. A similar scientific approach was used in [24], scientists have developed a technology of gluten-free bread based on rice flour using a mixture of potato and corn starch and sea buckthorn puree. It has been found that the content of magnesium, iron, zinc and vitamins A, E, C increases by $25 \%$, which provides $35-45 \%$ of the daily requirement for the above substances. In works [25, 26], to expand the range of bread with a high content of vitamins, it is proposed to use herbal raw materials. The technologies of bread "Bogatyr", "Shypshynka" with the use of hawthorn and rose hips have been developed. The developed types of bread provide the intake of $95-100 \%$ of vitamin $\mathrm{C}$ into the human body, have an increased content of vitamins A, D, E due to the use of phyto-raw materials.

The disadvantage of the developed technologies for the production of bread "Protein", "Carrot", "Beetroot" can be noted significant loss of nutrients during storage. The content of vitamins A, E, C decreases by $0.1 ; 0.7 ; 10.0 \mathrm{mg}$ in "Protein" bread, 1.3; 0.5; $20.0 \mathrm{mg}$ - in the "Carrot" bread, by $0.1 ; 0.2 ; 23 \mathrm{mg}-$ in "Beetroot" bread. The content of Fe, $\mathrm{Cu}$ in bread during storage decreases by $0.1 ; 0.012 \mathrm{mg}$ in "Protein" bread, by 2.0; $0.01 \mathrm{mg}$ - in "Carrot" bread, by 1.2; $0.02 \mathrm{mg}$ - in "Beetroot" bread (Table 6 ). The greatest losses are observed in the content vitamins of group B, in the future, the resulting deficiency can be eliminated due to the high content of vitamin E. It has been experimentally proven that the developed types of bread carry $\leq 100 \%$ of the daily requirement for vitamin $\mathrm{E}$, (Tables 5,6 ) will have a positive effect on the absorption of vitamins of group B during The study [27] proved the ability of vitamin E to positively affect the absorption of vitamins $\mathrm{B}_{6}, \mathrm{~B}_{9}, \mathrm{~B}_{12}$ by reducing self-assimilation.

The staling degree gluten-free bread was investigated. It was found that in the control sample of bread and "Protein" bread, which was stored for more than 48 hours, the complex organoleptic assessment of staling was 3.5 and 3.9 points, respectively. This classifies developed breads as stale. In the samples of bread "Carrot" and "Beetroot" the studied parameters were within the permissible levels and worsened only after 72 hours of storage (Table 7 ). The study of the structure of the crumb of bread made it possible to scientifically substantiate the biochemical changes that occurred during storage. As a result of research, it was found that the structure of the crumb of bread is an elastic mass of coagulated protein with starch, which makes up the spatial continuous phase of the crumb of bread (Fig. 1). In bread samples, where vegetable powders were used (Fig. 1), swollen pectin particles are observed, which are randomly distributed throughout the mass and have a rounded, slightly elongated shape, and are surrounded by a mass of coagulated proteins. The mass of coagulated protein with starch constitutes the spatial continuous phase of bread crumb, and pectin particles are impregnated into this system. In [28], the process of staling bread is explained by a change in the structural state of amylose and pectin. This process marks the high value of hydroxyl groups, which, in turn, are formed during the fermentation of the dough and give complexes with amylose and pectin, while slowing down the process of staling of bread. The change in the hydrophilic properties of the crumb of bread depends on the content of pectin and affects its microstructure and the degree of staling. In experimental studies [29] using pectin as a structure-forming component in gluten-free bread, a similar result was obtained - an increase in the implementation period. Taking into account the research results, it is advisable to store specialized bread according to the developed recipes for 48 hours after baking for "Protein" bread and 72 hours after baking for bread using vegetable powders.

The limitation of this study is that the content of legume flour in the gluten-free bread recipe should be no more than $10 \%$ due to the reduction of the buckwheat harrow. The content of vegetable powders should be up to $10 \%$ due to the reduction of potato starch. With such a ratio of prescription components, finished products using vegetable powders extend the sales period by one day. It is recommended to consume bread up to $270 \mathrm{~g}$ per day, taking into account the saturation of the human body with enriched nutrients without the possibility of exceeding the daily requirements for vitamins and microelements for which fortified products.

The development of this research consists in the established influence of the developed bread on the degree of its assimilation by the body during consumption. There are difficulties associated with the complexity of these studies. Study of the preventive, pharmacological properties of the product during consumption. One of the ways to solve the above problems is to conduct clinical trials on the basis of a medical institution. Clinical research is the only way to prove the efficacy and safety of any new specialized product, which is the prospect for further research.

\section{Conclusions}

1. It was found that in the composition of the carrot powder of the Daucus carota variety and the powder of the beet variety Beta vulgaris $L$. vitamins are found: A, E, C, $B_{1}$, $\mathrm{B}_{5}, \mathrm{~B}_{6}, \mathrm{~B}_{9}, \mathrm{~B}_{12}, \mathrm{~K}, \mathrm{PP}$ and microelements: $\mathrm{Ca}, \mathrm{Mg}, \mathrm{Fe}, \mathrm{Cu}$, I, Se, Zn. The content of vitamins A, E, C, B1, B ${ }_{5}, B_{6}, B_{9}, K$, $\mathrm{PP}$ in the composition of the carrot powder was $1.2 ; 0.40$; $16.00 ; 0.60 ; 1.30 ; 0.07 ; 0.05 ; 0.09 ; 6.00 \mathrm{mg}$ respectively. The content of trace elements $\mathrm{Ca}, \mathrm{Mg}, \mathrm{Fe}, \mathrm{Cu}, \mathrm{Se}, \mathrm{Zn}$ was 0.05 ; $13.5 ; 3.90 ; 0.035 ; 0.01 ; 1.3 \mathrm{mcg}$, respectively. The content of vitamins $\mathrm{C}, \mathrm{B}_{1}, \mathrm{~B}_{5}, \mathrm{~B}_{6}, \mathrm{~B}_{9}, \mathrm{~B}_{12}$ in the beet powder was 21.0; $0.50 ; 1.40 ; 0.09 ; 0.07 ; 0.01 \mathrm{mg}$, respectively. The content of 
trace elements: $\mathrm{Ca}, \mathrm{Mg}, \mathrm{Fe}, \mathrm{Cu}, \mathrm{I}, \mathrm{Zn}$ was $0.02 ; 12.5$ (mg) 1.6; $0.025 ; 0.01 ; 0.8 \mathrm{mcg}$, respectively.

The content of vitamins $\mathrm{A}, \mathrm{E}, \mathrm{C}, \mathrm{B}_{6}, \mathrm{~B}_{9}, \mathrm{~B}_{12}$ in soy flour was $0.2 ; 2.4 ; 19 ; 3.0 ; 0.4 ; 0.03 \mathrm{mg}$, respectively; and chickpea flour $-0.4 ; 3.8 ; 16 ; 0.35 ; 0.37 ; 0.028 \mathrm{mg}$, respectively. The content of trace elements $\mathrm{Mg}, \mathrm{Fe}, \mathrm{Cu}$, and, $\mathrm{Z}$ in the composition of soy flour was $410 ; 10,0.1 ; 50 ; 10 \mathrm{mcg}$, respectively. The content of trace elements $\mathrm{Mg}, \mathrm{Fe}, \mathrm{Cu}, \mathrm{Se}, \mathrm{Z}$ in the composition of chickpea flour was $335 ; 8.0,0.05 ; 52$; $11 \mathrm{mcg}$, respectively. Soy flour does not contain vitamins $\mathrm{B}_{1}$; $\mathrm{B}_{5}, \mathrm{~K}, \mathrm{PP}$ and trace element $\mathrm{Ca}$ and Se. The obtained data on the content of vitamins and microelements in chickpea flour differ from soy flour only in the content of Se, which is present in the developed product due to its accumulation during steeping. Powder from beet variety Beta vulgaris $L$. does not contain the microelement Se and vitamins A, E, $\mathrm{K}, \mathrm{PP}$, however, deficient vitamins $\mathrm{K}, \mathrm{PP}$ are found in the powder from carrot variety Daucus carota, but the content of Se is also absent.

2. The content of vitamins and microelements in bread during storage has been determined. It was found that the losses occur in the content of vitamins A, E, C and trace elements $\mathrm{Fe}, \mathrm{Cu}$. The content of vitamins A, E, C decreases by $0.1 ; 0.7 ; 10.0 \mathrm{mg}$ in "Protein" bread, $1.3 ; 0.5 ; 20.0 \mathrm{mg}$ - in "Carrot" bread, 0.1; 0.2; $23 \mathrm{mg}$ - in "Beetroot" bread. The content of $\mathrm{Fe}, \mathrm{Cu}$ decreases by $0.1 ; 0.012 \mathrm{mg}$ in "Protein" bread, by 2.0; $0.01 \mathrm{mg}$ - in "Carrot" bread, by 1.2; $0.02 \mathrm{mg}-$ in "Beetroot" bread. 72 hours after production, types of bread were developed that for the use of $100 \mathrm{~g}$ per day, they cover $50 \%$ of the daily requirement for fortified vitamins and minerals.

3. The staling degree of specialized bread was investigated. It has been established that the period for the sale of "Protein" bread is 48 hours. After the specified time, the bread is classified as stale in terms of porosity and fragility. The terms of sale of "Carrot" and "Beetroot" bread is 72 hours. The starch and pectin of vegetable powders affect the preservation of the quality indicators of bread. Analyzing the microstructure of the crumb of "Carrot" and "Beetroot" bread, it was found that the mass of curdled protein with starch constitutes a spatial continuous phase of the bread crumb, and pectin particles are impregnated into this system. This is the reason for the hydrophilic properties of the crumb of bread, expressed in a decrease in the degree of staling and an extension of the sale period.

\section{Acknowledgement}

The research was carried out within the framework of the state budget research theme No.0119U103577 "Scientific development of health food technology".

The authors express their gratitude to the staff of the "Educational and research laboratory of analytical, ecological researches" of the "Karazin Educational and Scientific Institute of Ecology".

\section{References}

1. Biletska, Y., Ryzhkova, T., Babenko, V., Krivtsova, A., Plotnikova, R., Skyrda, O. (2020). Substantiating the use of sprouted beans flour in the production of sour milk products based on goat milk. Eastern-European Journal of Enterprise Technologies, 4 (11 (106)), 6-13. doi: https://doi.org/10.15587/1729-4061.2020.209514

2. Biletska, Y., Djukareva, G., Ryzhkova, T., Kotlyar, O., Khaustova, T., Andrieieva, S., Bilovska, O. (2020). Substantiating the use of germinated legume flour enriched with iodine and selenium in the production of cooked-smoked sausages. Eastern-European Journal of Enterprise Technologies, 3 (11 (105)), 46-54. doi: https://doi.org/10.15587/1729-4061.2020.204796

3. Bird, L. G., Pilkington, C. L., Saputra, A., Serventi, L. (2017). Products of chickpea processing as texture improvers in gluten-free bread. Food Science and Technology International, 23 (8), 690-698. doi: https://doi.org/10.1177/1082013217717802

4. García-Segovia, P., Pagán-Moreno, M. J., Lara, I. F., Martínez-Monzó, J. (2017). Effect of microalgae incorporation on physicochemical and textural properties in wheat bread formulation. Food Science and Technology International, 23 (5), 437-447. doi: https://doi.org/ $10.1177 / 1082013217700259$

5. Boubaker, M., Omri, A. E., Blecker, C., Bouzouita, N. (2016). Fibre concentrate from artichoke (Cynara scolymus L.) stem byproducts: Characterization and application as a bakery product ingredient. Food Science and Technology International, 22 (8), 759-768. doi: https://doi.org/10.1177/1082013216654598

6. Tsykhanovska, I., Evlash, V., Alexandrov, A., Svidlo, K., Gontar, T. (2017). Influence of the polyfunctional food supplement "Magnetofood" on the quality of the wheat-rye bread "Kharkiv Rodnichok" in the storage process. Eastern-European Journal of Enterprise Technologies, 5 (11 (89)), 61-70. doi: https://doi.org/10.15587/1729-4061.2017.111522

7. Biletska, Y., Plotnikova, R., Skyrda, O., Bakirov, M., Iurchenko, S., Botshtein, B. (2020). Devising a technology for making flour from chickpea enriched with selenium. Eastern-European Journal of Enterprise Technologies, 1 (11 (103)), 50-58. doi: https://doi.org/ 10.15587/1729-4061.2020.193515

8. Beletska, Ya., Plotnikova, R., Bakirov, M., Vereshchynskyi, O. (2020). Development of the technology of soya flour enriched with iodine. Food Science and Technology, 14 (2). doi: https://doi.org/10.15673/fst.v14i2.1487

9. Tsykhanovska, I., Barsova, Z., Demidov, I., Pavlotskaya, L. (2015). Investigation of the oxidative and thermal transformations processes in the system «oil - lipids-magnetite suspension». Prohresyvni tekhnika ta tekhnolohiyi kharchovykh vyrobnytstv restorannoho hospodarstva i torhivli, 1 (21), 353-362.

10. Dziki, D., Różyło, R., Gawlik-Dziki, U., Świeca, M. (2014). Current trends in the enhancement of antioxidant activity of wheat bread by the addition of plant materials rich in phenolic compounds. Trends in Food Science \& Technology, 40 (1), 48-61. doi: https://doi.org/ 10.1016/j.tifs.2014.07.010 
11. Torres-León, C., Rojas, R., Contreras-Esquivel, J. C., Serna-Cock, L., Belmares-Cerda, R. E., Aguilar, C. N. (2016). Mango seed: Functional and nutritional properties. Trends in Food Science \& Technology, 55, 109-117. doi: https://doi.org/10.1016/ j.tifs.2016.06.009

12. Bharath Kumar, S., Prabhasankar, P. (2014). Low glycemic index ingredients and modified starches in wheat based food processing: A review. Trends in Food Science \& Technology, 35 (1), 32-41. doi: https://doi.org/10.1016/j.tifs.2013.10.007

13. Perspektyvy rozshyrennia asortymentu khlibobulochnykh vyrobiv dlia khvorykh na tseliakiu. Available at: http://hipzmag.com/ tehnologii/hlebopechenie/perspektivi-rozshirennya-asortimentu-hlibobulochnih-virobiv-dlya-hvorih-na-tseliakiyu/

14. Smolyar, V. I., Petrashenko, A. I., Golohova, E. V. (2014). Food fortification. Problemy kharchuvannia, 1, 29-32. Available at: http://pronut.medved.kiev.ua/index.php/ua/categories/original-researches/item/406-food-fortification

15. Petrenko, O. D. (2015). Effective and reliable control of the iodine content in the environment - an actual contemporary problem. Hihiena naselenykh mists, 65, 200-203. Available at: http://nbuv.gov.ua/j-pdf/gnm_2015_65_34.pdf

16. Arsenieva, L. Yu., Herasymenko, L. O., Antoniuk, M. M. (2004). Dosvid i perspektyvy zbahachennia khliba yodom. Problemy kharchuvannia, 1, 35-43. Available at: http://medved.kiev.ua/arh_nutr/art_2004/n04_1_6.htm

17. Biletska, Y., Babenko, V., Gusliev, A. (2019). Marketing studies of consumption preferences at developing dietary products. EUREKA: Social and Humanities, 5, 16-21. doi: https://doi.org/10.21303/2504-5571.2019.001009

18. Mykolenko, S. Yu., Hez', Y. V. (2017). Study of spelt and pumpkin flour influence on bread consumer characteristics. Prodovolchi resursy, 9, 228-234. Available at: http://nbuv.gov.ua/j-pdf/pr_2017_9_31.pdf

19. Liferova, A. I. (Ed.) (1964). Sbornik retseptur na hlebobulochnye izdeliya. Moscow: Ekonomika, 115.

20. Vyznachennia kryshkuvatosti khliba. Available at: https://studfile.net/preview/5152825/page:13/

21. Barna, É., Dworschák, E. (1994). Determination of thiamine (vitamin B,) and riboflavin (vitamin B2) in meat and liver by high-performance liquid chromatography. Journal of Chromatography A, 668 (2), 359-363. doi: https://doi.org/10.1016/ 0021-9673(94)80126-6

22. Toulis, K. A., Anastasilakis, A. D., Tzellos, T. G., Goulis, D. G., Kouvelas, D. (2010). Selenium Supplementation in the Treatment of Hashimoto's Thyroiditis: A Systematic Review and a Meta-analysis. Thyroid, 20 (10), 1163-1173. doi: https://doi.org/10.1089/ thy.2009.0351

23. Vasyukova, A. (2008). Vliyanie komponentov retseptury na kachestvo hlebobulochnyh izdeliy pri hranenii. Hleboprodukty, 8 , $50-51$.

24. Mykhonik, L., Gryshchenko, A. (2017). Using rice flour in the production technology of gluten-free bread. Scientific Works of NUFT, 23 (2), 241-247.

25. Lebedenko, T. E., Kananyhina, E. N., Sokolova, N. Yu., Rapita, V. R. (2010). Ispol'zovanie ekstraktov lekarstvennyh rasteniy v tehnologii hlebobulochnyh izdeliy. Naukovi pratsi [Odeskoi natsionalnoi akademii kharchovykh tekhnolohiy], 1 (38), 229-234.

26. Lebedenko, T. Ye., Novichkova, T. P., Kozhevnikova, V. O. (2014). The role of bakery products in formation of human health and methods of increasing their quality by the usage of phyto-additives. Visnyk Donetskoho natsionalnoho universytetu ekonomiky i torhivli im. Mykhaila Tuhan-Baranovskoho. Ser.: Tekhnichni nauky, 1, 79-89.

27. Lebiedzińska, A., Marszałł, M. L., Kuta, J., Szefer, P. (2007). Reversed-phase high-performance liquid chromatography method with coulometric electrochemical and ultraviolet detection for the quantification of vitamins B1 (thiamine), B6 (pyridoxamine, pyridoxal and pyridoxine) and B12 in animal and plant foods. Journal of Chromatography A, 1173 (1-2), 71-80. doi: https://doi.org/10.1016/ j.chroma.2007.09.072

28. Golubev, V. N. (1995). Pektin: himiya, tehnologiya, primenenie. Moscow: ARN, 387.

29. Butrim, S. M., Lisovskaya, L. G., Litvyak, V. V., Stolyarov, P. P. (2009). Ispol'zovanie v hlebopekarnoy promyshlennosti vodorastvorimyh krahmalov. Hlebopek, 2, 30-33. 